\title{
DAKWAH MELALUI PEMBINAAN KEAGAMAAN TERHADAP MASYARAKAT MUSLIM PEDALAMAN OLEH PENYULUH AGAMA ISLAM NON PNS KECAMATAN TEBAS, SAMBAS
}

\author{
Harles Anwar \\ Institut Agama Islam Negeri Palangkaraya, Kalimantan Tengah \\ harlesanwar@iain-palangkaraya.ac.id \\ Mualimin \\ Institut Agama Islam Negeri Palangkaraya, Kalimantan Tengah \\ mualimin@iain-palangkaraya.ac.id
}

\begin{abstract}
Abstrak
Tebas District is part of the $3 \mathrm{~T}$ region which has the largest population in Sambas district. Most of the population in the Tebas sub-district are spread in 23 villages where transportation access is quite alarming. This reality is not balanced with the number of non PNS Islamic religious instructors appointed by the Ministry of Religion, which amounted to only three people in 2019. Despite having limited personnel, the propaganda carried out with religious guidance was able to touch all circles and entire Tebas sub-district. This study aims to analyze da'wah through religious guidance carried out by Islamic religious instructors in the Tebas sub-district which is in the interior $(3 \mathrm{~T})$. This study is a field research using qualitative methods. The results of the analysis of the research findings can be concluded that the religious guidance carried out by Islamic religious instructors in the Tebas sub-district of Sambas district still uses a conventional coaching approach that emphasizes the delivery of da'wah messages orally and directly. Nonetheless, non-PNS Islamic religious instructors in Tebas district, Sambas district, their guidance efforts were carried out with a "pick up ball" pattern and were systematically scheduled. The selection of the guidance approach is based on the social reality of the missionary objectives that are still lagging behind both in terms of technology, access to information and transportation, and limited personnel resources in conducting guidance.
\end{abstract}

Keywoard : Da'wah, Religious Coaching, Islamic Religious Extension, 3 T, Tebas District 


\section{A. PENDAHULUAN}

Aktivitas dakwah belakang ini sering mendapatkan kritikan dari berbagai kalangan. Jamalie ${ }^{1}$ menyebutkan bahwa kritikan tersebut terfokus pada aktivitas dakwah yang cenderung hanya sekedar rutinitas dan formalitas saja. Hal ini karena dakwah yang saat ini dilakukan cenderung dilakukan secara normative saja tanpa mempertimbangkan dampak transformasi sosial. Selain itu kritikan lain juga muncul akibat aktivitas dakwah yang seringkali hanya menyentuh kalangan tertentu saja.

Dakwah pada dasarnya tidak hanya ditujukan pada kalangan tertentu, namun juga mesti dapat menyentuh berbagai kalangan. Shaleh dan Nandang ${ }^{2}$ menyebutkan bahwa dakwah yang dilakukan oleh Rasulullah tidak hanya ditujukan pada kalangan tertentu, tetapi justru pada semua kalangan. Hal ini karena tujuan akhir dari dakwah tersebut adalah untuk mewujudkan Islam Rahmatan lil 'Alamin. Namun realitasnya tidak semua aktivitas dakwah menyentuh seluruh elemen masyarakat terutama pada masyarakat pedalaman. Pada tataran ini, di satu sisi masyarakat pedalaman saat ini masih banyak yang memiliki keterbatasan dalam pengetahuan dan pemahaman keagamaan baik ritual maupun sosial. Namun disisi yang lain terdapat keterbatasan dan hambatan dalam melakukan dakwah pada masyarakat pedalaman. Hambatan dan keterbatasan tersebut terutama terkait sarana prasarana, kemauan pendakwah, dan hambatan jarak untuk mencapai lokasi sasaran dakwah.

Masyarakat pedalaman merupakan bagian dari kelompok masyarakat yang tinggal di daerah $3 \mathrm{~T}$ (terdepan, tertinggal, dan terluar). Masyarakat pedalaman ini dapat dikategorikan sebagai masyarakat marginal yang seringkali dipinggirkan dalam sasaran dakwah. Muhyiddin dan $\mathrm{Safei}^{3}$ menyebutkan bahwa

1 Zulfa Jamalie. 2015. "Pola Dakwah pada 'Masyarakat Suku Terasing' di Kalimantan Selatan. Jurnal Dakwah, Vol. 16 No. 1 tahun 2015

2 Komarudin Shaleh dan Nandang HMZ. 2016. “Dakwah pada Masyarakat Perkotaan: Studi Deskriptif Analisis terhadap Wijhah dan Aktivitas Dakwah Persis Pimpinan Daerah Kota Bandung". Prosiding SNaPP tahun 2016 hal 272

3 Asep Muhyiddin dan Agus Ahmad Syafei. Metode Pengembangan Dakwah. Bandung: Pustaka Setia 2002 Hal 153 
masyarakat marginal merupakan kelompok masyarakat yang terpinggirkan dari kehidupan baik dalam aspek pembangunan, fasilitas, maupun akses terhadap kehidupan perkotaan. Selain itu pada masyarakat marginal pemahaman, pengetahuan, dan persepsi keagamaan cenderung masih rendah. Merujuk pada pendapat tersebut maka aktivitas dakwah sangat diperlukan tidak hanya untuk meningkatkan pemahaman keagamaan, tetapi juga meningkatkan derajat kehidupan dalam berbagai bidang seperti pendidikan, sosial, ekonomi, dan budaya.

Kecamatan Tebas merupakan salah satu daerah yang masuk kategori $3 \mathrm{~T}$ yaitu terluar, terdepan, dan tertinggal. Sebagai daerah $3 \mathrm{~T}$, masih banyak masyarakat di kecamatan Tebas tinggal jauh dari pusat kota sehingga sulit di akses. Kecamatan ini terdiri dari 23 desa dan merupakan daerah dengan jumlah penduduk terbanyak di kabupaten Sambas. Selain itu mayoritas penduduk di kecamatan Tebas merupakan muslim. Meskipun demikian jumlah penyuluh agama Islam non PNS yang diangkat untuk wilayah kecamatan Tebas pada tahun 2019 hanya berjumlah 3 orang. Kondisi ini tentu tidak sebanding denga luas wilayah dan jumlah penduduk. Oleh karena itu wajar jika kemudian aktivitas dakwah mengalami berbagai hambatan.

Aktivitas dakwah penyuluh agama Islam kecamatan Tebas justru menyentuh sebagian besar daerah pedalaman dan yang sulit dijangkau. Berbagai program pembinaan keagamaan dilakukan justru berorientasi pada pemerataan sasaran dakwah tidak hanya pada wilayah yang mudah diakses, namun juga pada wilayah yang sulit untuk diakses. Program pembinaan keagamaan tersebut bahkan terjadwal secara tertulis, disusun sistematis, dan berkelanjutan untuk setiap tahunnya. Jadwal tersebut kemudian menjadi acuan dalam berbagai aktivitas dakwah penyuluh agama Islam di kecamatan Tebas.

Realitas dakwah yang dilakukan oleh penyuluh agama Islam non PNS di kecamatan Tebas merupakan sesuatu yang unik. Di satu sisi, jumlah personil yang diangkat oleh penyuluh agama cukup minim dan tidak seimbang dengan jumlah sasaran dakwah. Namun disisi lain aktivitas pembinaan keagamaan yang dilakukan penyuluh agama Islam non PNS justru mampu mencapai seluruh elemen masyarakat bahkan dilakukan terjadwal dan berkelanjutan. Realitas ini kemudian menjadi menarik untuk dikaji lebih lanjut dalam sebuah penelitian. 
Fokus kajian ini adalah dakwah yang dilakukan penyuluh agama Islam non PNS melalui pembinaan keagamaan pada masyarakat pedalaman di kecamatan Tebas kabupaten Sambas. Melalui kajian ini diharapkan berkontribusi bagi pengembangan dakwah pada masyarakat pedalaman. Selain itu juga hasil kajian ini diharapkan dapat menjadi masukan dalam perencanaan kebijakan dakwah oleh pihak yang berkepentingan khususnya Kementerian Agama dalam pengangkatan penyuluh agama Islam non PNS.

Kajian ini merupakan penelitian lapangan. Data dalam kajian ini didapatkan melalui tiga cara. Pertama, observasi dilakukan untuk memperoleh data tentang aktivitas dakwah yang dilakukan. Kedua, wawancara dilakukan untuk memperoleh data terkait strategi dakwah yang dilakukan. Ketiga, studi dokumenter digunakan untuk memperoleh data terkait jadwal pembinaan, proses pengangkatan penyuluh agama Islam non PNS. Data yang diperoleh kemudian diolah dan dianalisis menggunakan metode kualitatif.

\section{B. BENTUK PEMBINAAN KEAGAMAAN PADA MASYARAKAT PEDALAMAN}

Istilah penyuluh itu sendiri berasal dari kata suluh yang berfungsi sebagai alat penerangan ${ }^{4}$. Kata tersebut kemudian dihubungkan dengan kata agama yang pada dasarnya merujuk individu yang ditugaskan secara formal oleh pemerintah untuk melakukan pembinaan keagamaan kepada masyarakat. Dalam konteks ini penyuluh agama Islam Non PNS merupakan bagian dari individu yang diangkat dan ditugaskan oleh pemerintah untuk memberikan penyuluhan dan pembinaan keagamaan keislaman kepada masyarakat.

Abrasy memandang bahwa dakwah melalui pembinaan keagamaan merupakan bagian dari fokus utama dalam Islam. Pada tataran ini fokus dari misi kerasulan pada dasarnya upaya pembinaan keagamaan masyarakat. ${ }^{5}$ Penempatan pembinaan spiritualitas keagamaan juga menempati posisi yang lebih utama jika dibandingkan dengan pembinaan jasmani. Hal ini karena

4 Achmad Mubarok. Al-Irsyad An-Nafsy: Konseling Agama Teori dan Kasus. Jakarta: Bina Rena Prawira. 2000 hal 2

${ }^{5}$ Muhammad Athiyah al-Abrasy.. Dasar-dasar Pokok Pendidikan Islam. Jakarta: Bulan Bintang 1974 hal 15 
spiritualitas keagamaan akan berpengaruh terhadap kualitas akhlak dalam kehidupan sosial kemasyarakatan.

Sebagaimana fungsi dan tugas yang diberikan oleh pemerintah, berbagai upaya dilakukan oleh penyuluh Agama Islam non PNS Kecamatan Tebas. Secara umum setidaknya ada empat bentuk pembinaan keagamaan yang dilakukan secara rutin oleh penyuluh agama Islam non PNS di Kecamatan Tebas.

Pertama, safari dakwah. Bentuk pembinaan ini dilakukan dengan mendatangi masyarakat muslim secara langsung di berbagai tempat dalam wilayah Kecamatan Tebas. Safari dakwah dilakukan untuk memberikan penjelasan dan pembinaan keagamaan dengan sistem jemput bola kepada masyarakat. Oleh karena itu dalam pembinaan ini, penyuluh agama Islam secara pro-aktif melakukan pemetaan sasaran pembinaan yang menjadi prioritas. Selain itu, sasaran safari dakwah juga berdasarkan permintaan masyarakat.

Substansi pembinaan dalam safari dakwah ini adalah mencakup seluruh aspek permasalahan keagamaan masyarakat muslim kecamatan Tebas. Secara spesifik materi pembinaan juga biasanya disesuaikan dengan kebutuhan masyarakat yang menjadi sasaran safari dakwah. Selain itu materi dalam safari dakwah juga didasarkan pada permintaan masyarakat terkait penjelasan problematika keagamaan yang dialaminya. Oleh karena itu, substansi materi pembinaan dalam safari dakwah penyuluh agama Islam Kecamatan Tebas pada dasarnya bersifat fleksibel menyesuaikan dengan kebutuhan masyarakat.

Terdapat beberapa bentuk safari dakwah rutin dilakukan oleh penyuluh agama non PNS di Kecamatan Tebas. Setidaknya ada tiga bentuk safari dakwah dan merupakan target jamaah yang diprioritaskan yaitu safari BKMT, safari Jum'at, dan Safari PHBI. Safari BKMT sasaran dakwahnya adalah kelompek majelis taklim ibu-ibu rumah tangga. Pelaksanaan safari BKMT ini dilakukan dua kali dalam sebulan. Safari Jum'at dilakukan khusus pada hari Jum'at, dimana penyuluh agama Islam menyampaikan khutbah Jum'at dan memberikan pembinaan keagamaan sebelum shalat Jum'at dilakukan. Safari PHBI dilaksanakan pada setiap peringatan hari besar Islam, dimana penyuluh agama memberikan ceramah pada beberapa tempat.

Berbagai bentuk safari dakwah penyuluh agama Islam Kecamatan Tebas dilakukan secara rutin dan terjadwal. 
Perencanaan dan penjadwalan tersebut biasanya dilakukan di akhir tahun untuk jadwal tahun berikutnya. Melalui perencanaan dan penjadwalan tersebut pembinaan dilakukan lebih terarah. Jadwal yang telah disusun pada dasarnya menjadi patokan awal dalam pelaksanaan safari. Oleh karena itu masih memungkinkan pelaksanaan safari dakwah yang tidak didasarkan pada jadwal yang telah dibuat. Pelaksanaan yang tidak sesuai dengan jadwal tersebut terutama dalam kondisi tertentu seperti ada permintaan dari masyarakat, maupun kondisi tertentu yang mengharuskan pembinaan keagamaan segera kepada masyarakat. Oleh karena itu pelaksanaan safari dakwah oleh penyuluh agama Islam pada dasarnya terjadwal, namun tetap fleksibel menyesuaikan kebutuhan ummat.

Kedua, tanya jawab keagamaan. Pembinaan keagamaan melalui tanya jawab dilakukan untuk memberikan penjelasan atas permasalahan keagamaan yang dialami oleh umat Islam di Kecamatan Tebas. Pembinaan melalui tanya jawab keagamaan ini umumnya dilakukan secara langsung dan individual kepada penyuluh agama Islam. Oleh karena itu, penyuluh agama Islam kecamatan Tebas membuka layanan konsultasi keagamaan di rumah koordinator penyuluh agama kecamatan. Selain itu juga untuk mengakomodasi tingginya minat masyarakat untuk bertanya tentang permasalahan keagamaan disediakan juga layanan tanya jawab melalui SMS dan telepon.

Ketiga, pembinaan keluarga sakinah. Bantuk pembinaan yang ketiga ini dilakukan oleh penyuluh agama Islam kecamatan Tebas dalam rangka menekan tingkat perceraian yang cukup tinggi. Pembinaan keagamaan ini dilakukan secara rutin baik melalui layanan konsultasi keluarga sakinah, advokasi bagi korban kekerasan dalam rumah tangga, pelaksanaan BP4, maupun penyuluhan keluarga sakinah secara rutin di wilayah kecamatan Tebas.

Bentuk pembinaan keagaman yang dilakukan oleh penyuluh agama Islam kecamatan Tebas yang masih mengandalkan penyampaian pesan oral pada dasarnya dapat dimaknai dalam dua konteks. Pertama, aktivitas dakwah yang dilakukan masih menggunakan pendekatan konvensional karena penyampaian pesannya cenderung menggunakan pendekatan 
oral secara langsung. Menurut Uswatusolihah ${ }^{6}$ bentuk pembinaan secara konvensional melalui pesan oral ini masih banyak dilakukan hingga saat ini. Metode pembinaan melalui penyampaian oral juga masih dianggap cukup potensial untuk meningkatkan pengetahuan dan daya pikir sasaran dakwah. Pendapat tersebut sejalan dengan yang dikemukakan oleh Hasanah bahwa penyampaian pesan dakwah mesti dapat memberikan efek persuasif. Pada tataran ini penyampaian pesan dakwah melalui aktivitas oral dapat membangun kesefahaman antara pendakwah dan masyarakat sehingga secara tidak langsung dapat memberikan efek persuasif secara langsung jika dikemas dengan baik.

Merujuk pada pendapat di atas, bentuk pembinaan keagamaan yang mengedepankan penyampaian pesan oral secara langsung justru menjadi lebih efektif pada masyarakat pedalaman di kecamatan Tebas. Hal ini karena keterbatasan penguasaan teknologi dan informasi masyarakat pedalaman akan memungkinkan terjadinya miskomunikasi pesan dakwah yang disampaikan jika hanya mengandalkan media teknologi informasi dan komunikasi. Oleh karena itu dalam pembinaan keagamaan bagi masyarakat, modernisasi cara berdakwah sangat penting namun lebih utama lagi dakwah yang dilaksanakan dapat menimbulkan perubahan sosial keagamaan yang lebih baik dalam masyarakat. Hal ini sejalan dengan pandangan Muhtadi yang mengatakan bahwa tujuan utama dalam kegiatan dakwah adalah adanya transformasi perilaku keagamaan baik secara ritual maupun sosial dalam masyarakat 7 .

Kedua, penyuluh agama Islam kecamatan Tebas memahami karakteristik sosial kemasyarakatan sasaran dakwah yang dihadapi. Pemahaman tersebut terwujudkan dengan penyesuaian metode dan materi yang disampaikan pada sasaran dakwah. Pada tataran ini penyuluh agama Islam kecamatan Tebas melakukan aktivitas dakwah dengan menyesuaikan tingkat pendidikan, teknologi, dan kondisi sosial kemasyarakatan sasaran dakwah. Mufidah menyebutkan bahwa

6 Uus Uswatusolihah. 2010. "Public Communication dalam Dakwah Islam". Komunika: Jurnal Dakwah dan Komunikasi, Vol. 4 No. 2 tahun 2016. Ahl 131

7 Asep Saeful Muhtadi.. Komunikasi Politik Indonesia: Dinamika Islam Politik Pasca Orde Baru. Bandung: Remaja Rosdakarya2008 199 
pemahaman tentang karakter sasaran dakwah menjadi suatu keharusan bagi penyuluh agama Islam. Bahkan pengetahuan dan pemahaman tentang karakteristik sasaran dakwah menjadi agenda pertama yang mesti dilakukan sebagai bahan perencanaan dan persiapan pelaksanaan dakwah ${ }^{8}$.

Pembinaan keagamaan yang dilakukan oleh penyuluh agama Islam kecamatan Tebas yang bertemu langsung dengan masyarakat dapat membentuk hubungan emosional antara tokoh agama dan masyarat. Menurut Suryanagara kedekatan hubungan antara tokoh agama dan masyarakat menjadi faktor penting dalam keberhasilan dakwah'. Pada tataran ini masyarakat akan senantiasa memberikan perhatian dan simpatinya pada setiap aktivitas dakwah yang dilakukan oleh tokoh agama tersebut. Kondisi inilah juga yang menjadi faktor penentu keberhasilan dakwah Walisongo dalam menyebarkan Islam di Indonesia.

Pembinaan keagamaan yang dilakukan oleh penyuluh agama Islam yang tidak hanya terfokus pada substansi keagamaan dan ritual saja menunjukkan adanya transformasi paradigma dakwah yang dilakukan. Menurut Nugraha selama ini aktivitas dakwah hanya diasosisikan pada persoalan ritual ibadah saja, padahal Islam memiliki spirit pembebasan yang menyeimbangkan hablumminallah dan hablumminannas ${ }^{10}$. Oleh karena itu dakwah Islam mestinya mampu menjawab tidak hanya problematika ritual ibadah saja, namun juga problematika kemanusiaan dalam masyarakat. Engineer dalam konteks ini memandang bahwa dakwah yang dilakukan oleh Nabi Muhammad bukan hanya untuk penyebaran akidah, tetapi juga merubah struktur sosial masyarakat menjadi lebih baik.11

8 Fatatun Mufidah. 2015. “Upaya Penyuluh Agama Islam Kementerian Agama Kabupaten Jember dan Bondowoso terhadap Pengembangan Dakwah". At-Tatwir, Vol. 2 No. 1 tahun 2015 hal 77

${ }_{9}$ Ahmad mansyur Suryanagara.. Menemukan Sejarah. Bandung: Mizan 1995 hal 108

10 Firman Nugraha. 2013. "Penyuluhan Agama Transformatif: Sebuah Model Dakwah". Jurnal Ilmu Dakwah, Vol. 7 No. 21 tahun 2013 hal 17

11 Asghar Aki Engineer. Devolusi Negara Islam. Yogyakarta: LKiS. 2000 hal 19 


\section{TANTANGAN DAN HAMBATAN PEMBINAAN KEAGAMAAN PADA MASYARAKAT PEDALAMAN}

Pembinaan keagamaan oleh penyuluh agama Islam non PNS di kecamatan Tebas tidak selalu terlaksana dengan sebagaimana mestinya. Seringkali ditemukan berbagai hambatan dalam pelaksanaan pembinaan dilapangan. Secara umum setidaknya ada dua hambatan dan tantangan dalam pelaksanaan pembinaan keagamaan di kecamatan Tebas.

Pertama, lokasi sasaran dakwah yang sulit dijangkau. Masyarakat pedalaman di kecamatan Tebas tinggal secara berkelompok di wilayah tertentu. Penyuluh agama Islam seringkali dihadapkan pada kesulitan untuk mencapai lokasi binaan karena letaknya yang cukup jauh. Seringkali untuk untuk mencapai lokasi binaan harus ditempuh selama 4 jam. Selain itu penyebab lain yang semakin mempersulit untuk menjangkau lokasi binaan adalah akses jalan yang kurang memadai. Kondisi ini semakin sulit ketika musim hujan, dimana jalan yang harus dilalui berlumpur sehingga seringkali mengakibatkan kerusakan kendaraan yang digunakan penyuluh agama Islam.

Kedua, kesibukan masyarakat dalam mencari nafkah. Sebagian besar sasaran dakwah di pedalaman kecamatan Tebas mata pencahariannya terkait erat dengan alam. Pada tataran ini pekerjaan dengan mengelola sumber alam tentu memerlukan tenaga dan waktu yang cukup besar bagi masyarakat. Secara tidak langsung hal tersebut menyebabkan kelelahan bagi masyarakat setelah bekerja. Kondisi ini kemudian menjadi hambatan bagi masyarakat untuk menghadiri berbagai pembinaan yang dilakukan oleh penyuluh agama.

Hambatan dapat ditemui dalam berbagai program dan agenda pembinaan keagamaan di masyarakat. Oleh karena itu diperlukan strategi yang efektif dalam mengatasi berbagai permasalahan tersebut. Ahmad menyebutkan bahwa agar dakwah menjadi efektif maka harus dilakukan menggunakan cara-cara strategis dan tepat sasaran. Sejalan dengan pendapat di atas ${ }^{12}$, Hadisaputra memandang bahwa hambatan dan tantangan dalam berdakwah pada dasarnya merupakan sebuah sunnatullah

12 Nur Ahmad. 2013. “Tantangan Dakwah di Era Teknologi dan Informasi; Formulasi Karakteristik, Popularitas, dan Materi di Jalan Dakwah". At-Tabsyir: Jurnal Komunikasi Penyiaran Islam, Vol. 1 No. 1 tahun 2013 hal 42 
yang mesti dihadapi oleh setiap pendakwah. ${ }^{13}$ Oleh karena itu setiap pendakwah mesti memiliki keterampilan metode dakwah dan kejelian dalam menganalisis setiap permasalahan yang muncul. Melalui analisis tersebut kemudian dapat dirumuskan strategi yang tepat dalam mengatasi permasalahan dan hambatan dakwah.

Strategi yang dilakukan penyuluh agama Islam kecamatan Tebas menghadapi dalam hambatan pembinaan keagamaan tersebut adalah dengan melakukan perencanaan dan pemetaan sasaran dakwah. Aspek-aspek yang menjadi pertimbangan dalam perencanaan tersebut yaitu aspek cuaca, jarak tempuh, aspek prioritas sasaran binaan, prediksi dinamika sosial kemasyarakatan, PHBI, dan kesediaan personil penyuluh agama Islam. Hasil dari perencanaan dan pemetaan yang dilakukan kemudian dituangkan dalam jadwal kegiatan pembinaan untuk satu tahun. Jadwal tersebut kemudian menjadi acuan awal dalam pelaksanaan pembinaan keagamaan masyarakat pedalaman di kecamatan Tebas.

Aspek perencanaan dan pemetaan memainkan peranan yang sangat penting dalam keberhasilan dakwah. Perencanaan dan pemetaan dalam dakwah menurut Kusnawan berfungsi sebagai pedoman pelaksanaan, pengendalian dan antisipasi hambatan dalam mencapai suatu tujuan yang ingin dicapai ${ }^{14}$. Mualimin memandang bahwa perencanaan menjadi salah satu faktor penentu dalam mencapai tujuan dakwah. Pada tataran ini berhasil atau tidaknya suatu tujuan dicapai tergantung dari bagaimana perencanaan dilakukan. Oleh karena itu diperlukan kematangan dalam melakukan perencanaan dakwah. ${ }^{15}$

Selain itu untuk menghadapi hambatan jarak dengan sasaran dakwah, penyuluh agama Islam kecamatan Tebas menggunakan strategi pembinaan melalui SMS dan sambungan

13 Sami'an Hadisaputra. 2012. "Problematika Komunikasi Dakwah dan Hambatannya: Perspektif Teoritis dan Fenomenologis". Jurnal Adzikra, Vol. 03 No. 1 tahun 2012hal 66

14 Aep Kusnawan. 2010. "Perencanaan Pendidikan Tinggi Dakwah Islam". Ilmu Dakwah: Academic Journal for Homiletic Studies, Vol. 5 No. 15 taun 2010 hal 904

15 Mualimin. 2017. “Manajemen Dakwah melalui Bantuan Kemanusiaan Korban Banjir di Kabupaten Sambas". Ilmu Dakwah: Academic Journal for Homiletic Studies, Vol. 11, No. 1 tahun 2017 hal 120 
telepon. Strategi ini digunakan terutama pada pertanyaan masyarakat atas permasalahan keagamaan yang dihadapinya, sehingga bisa langsung diberikan solusi. Permasalahan tersebut kemudian akan menjadi topik bahasan ketika pembinaan dilakukan ditempat masyarakat yang bertanya tersebut. Strategi lain yang dilakukan adalah berkoordinasi dan bekerjasama dengan ormas Islam yang ada di kecamatan Tebas untuk melaksanakan pembinaan. Koordinasi dan kerjasama ini memungkinkan agar aktivitas dakwah dilakukan secara sinergis oleh setiap elemen masyarakat sehingga akan menimbulkan efek yang lebih besar terhadap keberhasilan dakwah.

Kerjasama dalam pelaksanaan dakwah merupakan aspek lain yang juga berkontribusi besar terhadap keberhasilan dakwah. Abdullah memandang bahwa kerjasama antar organisasi dakwah memiliki peran yang cukup penting dalam mengatasi berbagai kelemahan yang dihadapi dalam berdakwah. Melalui kerjasama tersebut kelemahan dan permasalahan yang dihadapi dalam berdakwah dapat diselesaikan secara bersama dengan saling memberikan dukungan dan bantuan ${ }^{16}$. Raihan juga memandang bahwa pencapaian tujuan dalam dakwah dapat ditempuh dengan pemanfaatan sumber daya dan sarana dakwah melalui kerjasama antara pihak yang berkepentingan. Lebih jauh lagi menurut Simanungkalit dan Anna memandang bahwa kerjasama memberikan kontribusi dan pengaruh yang cukup besar terhadap efesiensi dan upaya pencapaian suatu tujuan. Merujuk pendapat di atas, strategi kerjasama dan koordinasi yang digunakan penyuluh agama Islam kecamatan Tebas merupakan langkah yang tepat untuk mengatasi berbagai hambatan dan tantangan dakwah pada masyarakat pedalaman. ${ }^{17}$

\section{SIMPULAN}

Berdasarkan pembahasan di atas, dapat disimpulkan bahwa pembinaan keagamaan yang dilakukan oleh penyuluh agama Islam kecamatan Tebas kabupaten Sambas masih

16 Abdullah. 2012. "Analisis Swot Dakwah di Indonesia: Upaya Merumuskan Peta Dakwah". Miqot, Vol. 36 Vol. 2 tahun 2012.hal 418

17 Dina Rolanna Simanungkalit dan Lucy Anna. 2013. “Analisis Hubungan Kerjasama Tim Untuk Meningkatkan Efisiensi Kerja pada PT Mitha Samudera Wijaya Medan". Media Informasi Manajemen, Vol. 1 No. 4 tahun 2013. 
menggunakan pendekatan pembinaan konvensional yang menekankan penyampaian pesan dakwah secara oral dan langsung. Meskipun demikian, penyuluh agama Islam non PNS kecamatan Tebas kabupaten Sambas upaya pembinaannya dilakukan dengan pola "jemput bola" dan terjadwal secara sistematis. Pemilihan pendekatan pembinaan tersebut didasari pada realitas sosial sasaran dakwah yang belum tersentuh secara merata teknologi informasi. Selain itu pertimbangan lainnya adalah untuk menghindari kesalahfahaman terhadap substansi materi dakwah yang disampaikan oleh penyuluh agama Islam kecamatan Tebas. Selain itu keterbatasan sumberdaya dan hambatan jarak juga menjadi pertimbangan dalam pendekatan pembinaan yang dilakukan.

\section{DAFTAR PUSTAKA}

Abdullah. 2012. "Analisis Swot Dakwah di Indonesia: Upaya Merumuskan Peta Dakwah". Miqot, Vol. 36 Vol. 2 tahun 2012.

Achmad Mubarok. 2000. Al-Irsyad An-Nafsy: Konseling Agama Teori dan Kasus. Jakarta: Bina Rena Prawira.

Aep Kusnawan. 2010. "Perencanaan Pendidikan Tinggi Dakwah Islam". Ilmu Dakwah: Academic Journal for Homiletic Studies, Vol. 5 No. 15 taun 2010.

Ahmad mansyur Suryanagara. 1995. Menemukan Sejarah. Bandung: Mizan.

Asep Muhyiddin dan Agus Ahmad Syafei. 2002. Metode Pengembangan Dakwah. Bandung: Pustaka Setia.

Asep Saeful Muhtadi. 2008. Komunikasi Politik Indonesia: Dinamika Islam Politik Pasca Orde Baru. Bandung: Remaja Rosdakarya.

Asghar Aki Engineer. 2000. Devolusi Negara Islam. Yogyakarta: LKiS.

Dina Rolanna Simanungkalit dan Lucy Anna. 2013. “Analisis Hubungan Kerjasama Tim Untuk Meningkatkan Efisiensi 
Kerja pada PT Mitha Samudera Wijaya Medan". Media Informasi Manajemen, Vol. 1 No. 4 tahun 2013.

Fatatun Mufidah. 2015. “Upaya Penyuluh Agama Islam Kementerian Agama Kabupaten Jember dan Bondowoso terhadap Pengembangan Dakwah". At-Tatwir, Vol. 2 No. 1 tahun 2015.

Firman Nugraha. 2013. "Penyuluhan Agama Transformatif: Sebuah Model Dakwah". Jurnal Ilmu Dakwah, Vol. 7 No. 21 tahun 2013.

Hasyim Hasanah. 2016. “Arah Pengembangan Dakwah melalui Sistem Komunikasi Islam". At-Tabsyir: Jurnal Komunikasi Penyiaran Islam, Vol. 4 No. 1 tahun 2016.

Komarudin Shaleh dan Nandang HMZ. 2016. “Dakwah pada Masyarakat Perkotaan: Studi Deskriptif Analisis terhadap Wijhah dan Aktivitas Dakwah Persis Pimpinan Daerah Kota Bandung". Prosiding SNaPP tahun 2016.

Mualimin. 2017. "Manajemen Dakwah melalui Bantuan Kemanusiaan Korban Banjir di Kabupaten Sambas". Ilmu Dakwah: Academic Journal for Homiletic Studies, Vol. 11, No. 1 tahun 2017.

Muhammad Athiyah al-Abrasy. 1974. Dasar-dasar Pokok Pendidikan Islam. Jakarta: Bulan Bintang.

Nur Ahmad. 2013. “Tantangan Dakwah di Era Teknologi dan Informasi; Formulasi Karakteristik, Popularitas, dan Materi di Jalan Dakwah". At-Tabsyir: Jurnal Komunikasi Penyiaran Islam, Vol. 1 No. 1 tahun 2013.

Raihan. 2014. "Kepemimpinan di dalam Manajemen Dakwah". Jurnal Al-Bayan, Vol, 21 No. 30 tahun 2014.

Sami'an Hadisaputra. 2012. "Problematika Komunikasi Dakwah dan Hambatannya: Perspektif Teoritis dan Fenomenologis". Jurnal Adzikra, Vol. 03 No. 1 tahun 2012.

Uus Uswatusolihah. 2010. "Public Communication dalam Dakwah Islam". Komunika: Jurnal Dakwah dan Komunikasi, Vol. 4 No. 2 tahun 2010. 
36 | Bimbingan Penyuluhan Islam, Vol. 1, No. 1 Januari-Juni 2019

Zulfa Jamalie. 2015. "Pola Dakwah pada 'Masyarakat Suku Terasing' di Kalimantan Selatan. Jurnal Dakwah, Vol. 16 No. 1 tahun 2015. 